\title{
A survey on how social support, medical care and nursing impacts on the quality of women's lives after mastectomy
}

\author{
Małgorzata Kaczmarkiewicz, Stanisław Sporny \\ State Higher Vocational School in Kalisz, Poland
}

\begin{abstract}
Rates of breast cancer continue to grow along with the number of patients undergoing mastectomy. Breast cancer needs therefore to be detected as early as possible by means of more frequent and largescale screening. This could thereby improve treatment outcomes and afford protection in some women against aggressive forms of cancer treatment.

Although the general public has increasingly become more cancer-aware, people still seek medical attention too late. Detrimental changes in breast tissue are often at an advanced stage and thus require treatment; unfortunately involving mastectomy.

For women the breast is regarded as vital symbol of femininity and motherhood, and so it is easily understandable how breast removal adversely affects a woman's mental wellbeing, her physical state and social situation. The increasing numbers of women patients after aggressive breast surgery require care, medical assistance and support, primarily from loved ones but also from medical staff and society in general. Good will and empathy are needed at different times during one's life, both in health and in disease; this being particularly essential to women after breast surgery. It is important that such patients are motivated and supported when facing their breast cancer. Breast cancer sufferers have to struggle hard for their health and life, where they require comprehensive physical and mental rehabilitation so that they can best cope with family life and in general society.

The study was undertaken in Kalisz, Poland by the 'Amazon Club' in Kalisz and the Private Specialist Health Care Oncology Clinic. One of the study aims was to investigate the circumstances in which a diagnosis had been made. As aforementioned, despite society's growing cancer awareness, women are diagnosed late and their breast cancer is so advanced as to require aggressive surgery. Most of those surveyed in our study ( 48 women; $60 \%$ ) found changes in their breast during self-examination. Another aim was to subjectively assess the social support received by the subjects from the time of diagnosis and then throughout treatment; particularly regarding the acceptance of family and friends. We found that, at diagnosis, 29 subjects (36\%) reported greatest support from their family and for 16 (20\%) this came from 'Amazon Club' members as well as their families.

Subjects who found acceptance from their life-partner and close family reported that they felt no need for breast reconstruction and accepted themselves as they are.

Following their breast surgery, a further study aim was to also evaluate the effect of medical treatment, nursing care and patient education on the patient's family and professional life. We found that 30 subjects (37\%) reported that most of the information they obtained at diagnosis came from the doctor, however this was by no means exhaustive as the subjects themselves make clear.

It is vital for such women after diagnosis to be entered into special psychological care programs. Nevertheless we found that 50 subjects $(62 \%)$ were not covered by any such programs. Not all women showed such a need, however it is important that all patients can, if they so wish, have access to such help. It is concluded that full and informed knowledge on treatment, nursing care and help in every-day living, including physiological support, can most certainly improve the lives of women after mastectomy.
\end{abstract}

KEY WORDS: support, mastectomy, education. 


\section{INTRODUCTION}

Breast cancer is the most common type of cancer found in women. It still poses a major threat to health and life. Due to medical advances, much progress has been achieved in winning this battle. Nonetheless, a large proportion of women in Poland do not perform a self breast examination and thereby do not undertake preventative testing. Breast cancer risk increases with age. Before age 35 years, breast cancer incidence is $1-3 \%$ but is of a pronouncedly invasive nature.

However, breast cancer rates significant rise after the age of 50, reaching a median at around 60 years. Indeed, women with breast cancer aged 50-59 years constitute $32 \%$ of all cases of this type of cancer [1]. Those discovering a lump in their breast upon self-examination are often reluctant to go to their doctor due to the fear of receiving a breast cancer diagnosis; often perceived as a death sentence.

The very word 'cancer' is always frightening and breast cancer is especially threatening (Baum, Saunders, Meredith, 1995) [2]; hence visiting the doctor is delayed. Women are fearful of surgical injury. Apart from the concern over breast removal and disfigurement, there is the worry about people's rejection; particularly by their loved ones. People are scared of cancer and don't even wish to discuss it. Just talking about it to people and receiving support and acceptance are however very important to women sufferers and those after mastectomy.

A women who after breast removal, that is unable to talk about her loss and suffering, her fear of being and of finding her place in the world will shut inside herself off and become distant from others, under the guise of self-control and courage. This is a concealed loneliness, fear and anger whereas women after mastectomy very much need the support of their family and other people and the feeling of being accepted as a woman. Above all else, it is a long struggle with an illness that will always be 'lurking' during their lifetime [3].

Technological advances in all walks of life, including medicine, have often made one forget about the really important things in life. For every person, especially those ill, a sense of a purpose in life becomes very significant. To sufferers, this is closely connected to hope, faith, a better tomorrow and the possibility of being cured. A large part of society regards cancer as a sentence, whereas many sufferers actually are cured. It is important to convince the patient to fight this disease, which although being difficult, can prove successful.

To achieve this, patients must believe and feel that they have around them all that they most need, i.e. sympathetic persons and the support of society given by people they come into contact with, as well as medical care providers [3].

In the context of the study aims for investigating the effect of social and medical support to women post-mastectomy, the following issues require consideration:
1. The number of women diagnosed with breast cancer and undergoing aggressive surgery is annually increasing.

2. Breast removal has an enormous impact on the physical condition, mental wellbeing and the social situation of women.

3. Post-mastectomy women constitute a large group that require medical care together with much support from their families, friends and their surroundings.

4. One of the most stressful experiences are women suffering cancer and, in greater or lesser extent, this fear and anxiety about one's health lasts a lifetime.

There is much scientific literature on the prevention, diagnosis and genesis of breast cancer, however dealing with women's lives post-mastectomy has received scant attention. Gaining more knowledge in this area would help in rehabilitating such patients; physically, psychologically and psychosocially. Wider information on the problems facing women with breast cancer and how best to deal with them would thereby improve their care and support in areas where they are most needed.

For women to subjectively assess themselves postmastectomy, on their received medical care and critically analyze the effect of social support, medical care and nursing care has on their family and professional lives. The patient's point of view forms the basis for assessing health care and can be used to verify the outcomes of their received healthcare [4].

The following was first considered:

- circumstances in which the diagnosis was made,

- subjectively assessing the social support provided at diagnosis and throughout treatment,

- the knowledge acquired about the treatment, preparation for surgery, and lifestyle for living after surgery,

- effect of health care, nursing, and patient education post-mastectomy for continuing on with their family and professional life.

\section{MATERIAL AND METHODS}

Subjects were 80 women aged $42-82$ years who had undergone mastectomy following a diagnosis of breast cancer. The study was conducted at the Kalisz 'Amazon Club' (28a Staszica Street) and the Private Specialist Health Care Oncology Clinic ('Przy Rogatcie' at 34 Srodmiejska Street) located at the Kalisz Old Town district.

The survey consisted of an in-house developed questionnaire which included open and closed questions in order to address the study aims. All women were informed about the purpose of the study, the use of results and their anonymity was assured.

\section{RESULTS AND DISCUSSION}

Over half the subjects (60\%) reported that diagnosis was made during self-examination thereby demonstrat- 


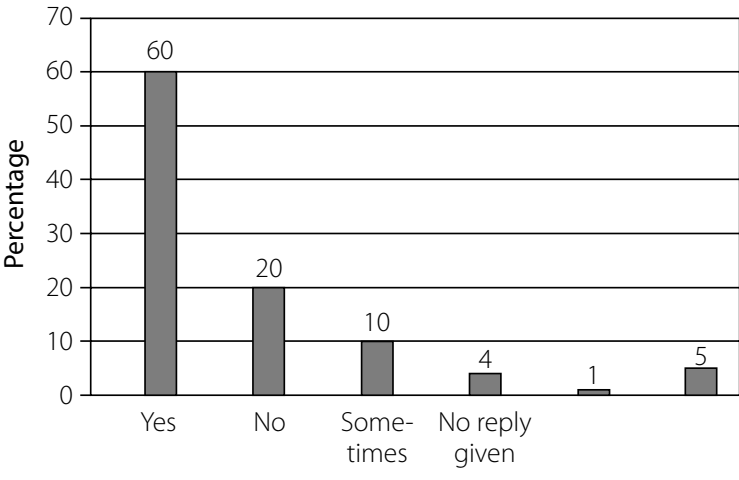

FIGURE 1. Circumstances leading to the diagnosis of breast cancer

ing an increasing awareness of breast cancer prevention measures. Their knowledge was not however yet at a level where they would have been willing to undergo mammography screening. Diagnosing the disease during screening occurred in only 8 patients (10\%) (Fig. 1).

Regular breast self-examination reflects a greater concern about one's health and a higher health awareness (Figs. 2 and 3). People who regularly examine their breasts tend to recognize that any change in the breast should always be verified by experts, thus leading to an early diagnosis [5].

This however can never replace screening, whose aim is to detect breast cancer as early as possible and thereby reduce mortality. Those about to be screened, do not have symptoms of the disease, hence the screening is carried out to as early as possible detect any cancer or pre-cancerous stages.

The risk of breast cancer increases with age. Table 1 shows the number of cancer cases in women subjects at the various decades of their life. A significant increase in cancer rates occur during VI and VII life decade.

Breast cancer screening guidelines vary according to the organizations conducting this research. The EU expert committee on Mammography Screening recommends that screening should cover women aged 50-69 years and that testing should be done every 2 or 3 years thereafter. In contrast, the American Cancer Society recommends a mammography every year in conjunc-

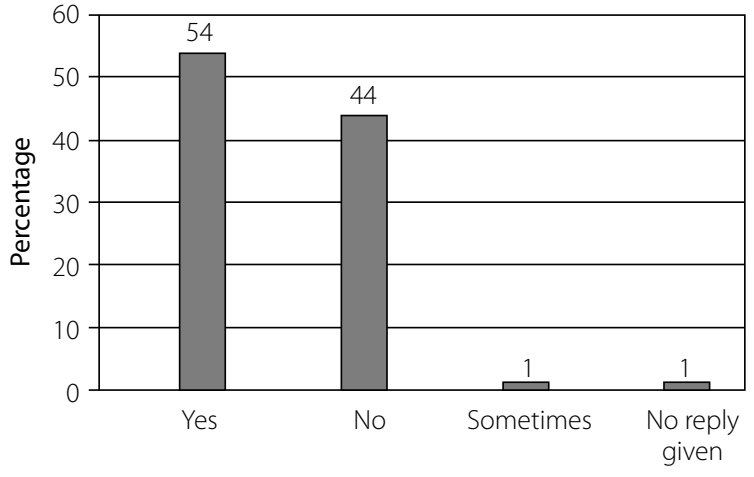

FIGURE 2. Numbers of women that self-examined their breasts before diagnosis

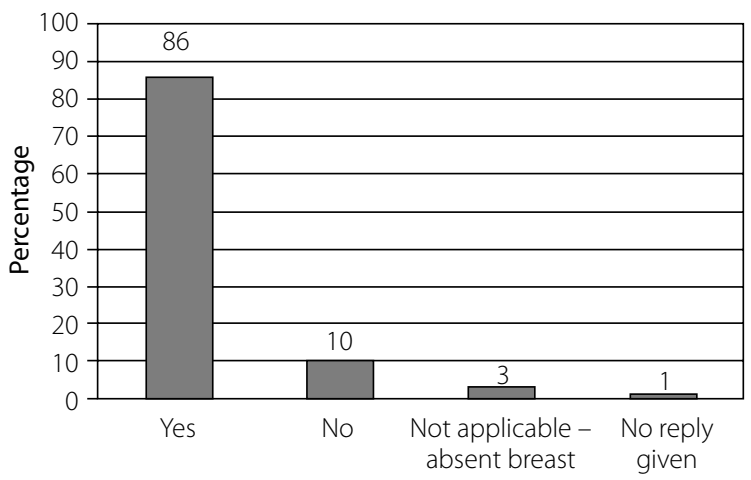

FIGURE 3. Numbers of women post-mastectomy that self-examine their remaining breast

tion with a clinical examination of the breast for those women above 40 years. The US National Cancer Institute (NCI) states that a mammography, with or without palpation, should be performed in women aged 40 years and above, and at 1-2 year intervals thereafter [5].

In the light of such recommendations, Polish women need to educated more about cancer prevention and treatment, along with having guaranteed access to screening. Women should also be encouraged to have tests more often if there is any family history of breast cancer (Fig. 4).

During one's life, many difficult situations and problems are encountered daily. However some random

TABLE 1. Number of breast cancer cases at defined decades of life (4 patients declined to give their ages)

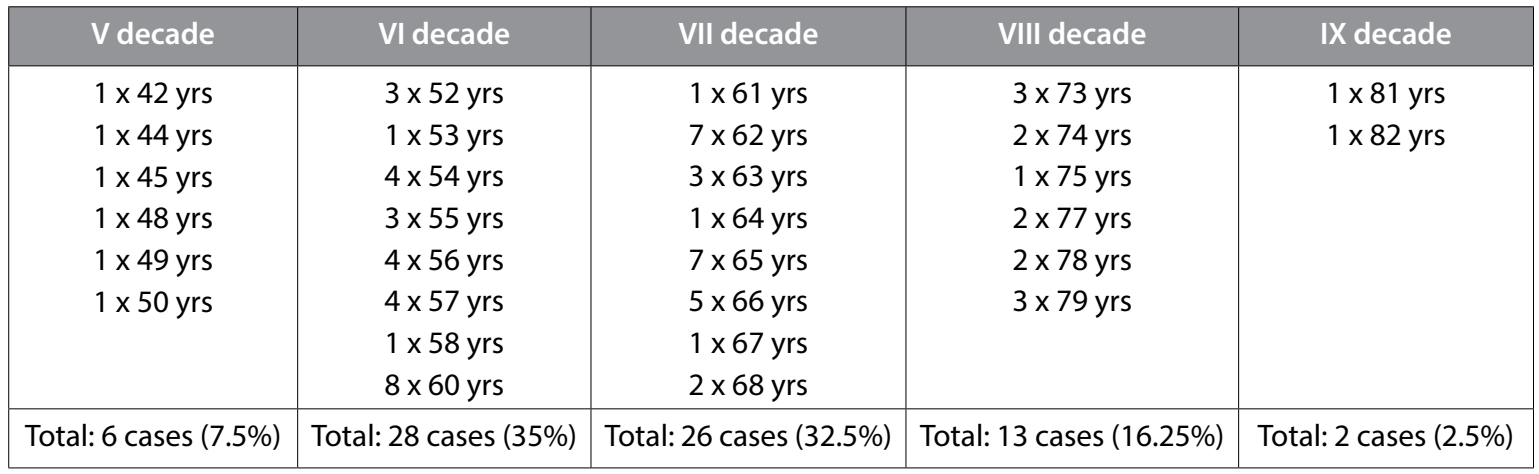




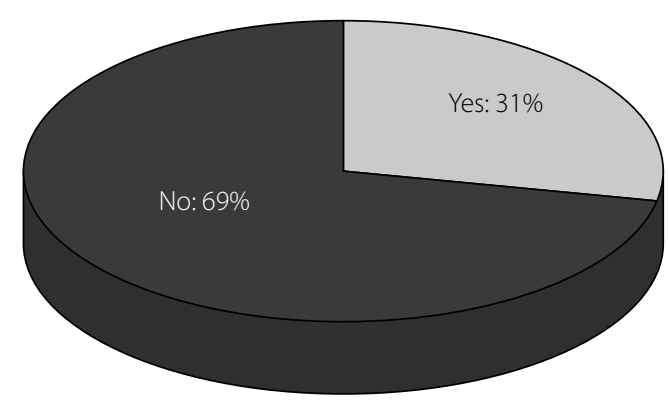

FIGURE 4. Family history breakdown of previous breast cancer

events occur that can take one completely by surprise, forcing a change of existing plans, daily routine, duties to be performed or in habits. Breast cancer is one of those unforeseen and traumatic events for which a mastectomy is frequently required as treatment.

Such situations force women sufferers to confront the many adverse effects of the disease and treatment, where a state of helplessness, anxiety and fear is induced and the patient just doesn't know what to do. It is therefore vital to be aware of existing social support systems [3]; as all researchers in this area readily acknowledge, who are engaged in the area of human experience, is being aware of social support systems [3].

At various times over one's life, and in many instances, just receiving support from a single source can be of major importance, eg. medical staff support during sickness, whereas support from other sources may seem less so. In order that the sick person receives the needed support, it becomes necessary to know the structure of their family, which should be a source of support for the patient in their battle against the disease. This is however not always the case.

Women with breast cancer are greatly supported by volunteers and those working in 'Women After Mastectomy' clubs. A volunteer could be anyone who has the willingness, spare time and appropriate psychological

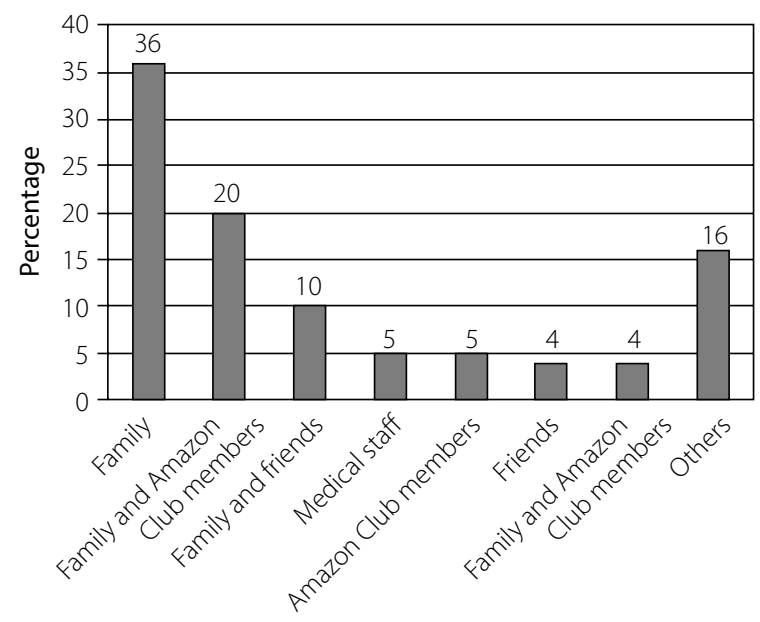

FIGURE 5. Sources of support found after breast cancer diagnosis and during treatment predisposition. They should also be a woman who has had personal experience of going through breast cancer and mastectomy thus constituting a rich baggage of traumatic experience and a certain distance towards such circumstances. In addition, such volunteers should feel healthy, strong and be responsible enough to realize that her efforts and contacts with patients should bring them aid and have beneficial effects. On the other hand, if such situations are handled incompetently, without imagination and sensitivity, then the patient suffers. For such reasons volunteers need to be adequately prepared and possess the ability to work under appropriate professional guidance and supervision [3].

The study subjects stated that they received the most support during treatment and thereafter outside their families from 'Amazon Club' members (Fig. 5).

When asked what other benefits does membership in the club bring them, they say it's because someone else has felt the same as me and understands how I now feel along with realizing that one has the ability to live and work whilst still having the disease.

In Poland, the Amazons Movement arose thanks to the initiative of doctors, who were inspired by the American Amazons. The first club was created in 1987 at the Department of Rehabilitation in the Warsaw Center of Oncology at the initiative of Dr. Krystyna Mika who began developing the Amazons Movement in Poland and contributed to the establishment of similar clubs throughout the whole country.

The reason however, for the movement's creation was not due to women's protest or discontent, as in the United States, but the desire to support patients who were unable to cope alone with the consequences of having cancer and the side-effects of treatment [6].

Any illness in one's family is a worry to all concerned. Cancer however, is a real shock for everyone especially that in our society the word cancer, is commonly associated with something very final ie. death. It is therefore very important to educate patients and their families. In this respect the nurses role is crucial. They have the most frequent contact with the patient and its manner will depend on gaining the patient's trust which in turn will make the patient more adaptable to the difficult situations facing them during treatment and to help them in their battle against cancer.

Overcoming emotions is very important, as well as gaining patient support for improving the effectiveness of treatment. Obtaining the full confidence of the patient and their faith in a successful outcome should be a priority [7].

Any disease, particularly cancer affects both the physical condition and mental state of the patient, where sick persons form a self-image of their suffering.

I. Heszen-Clement (1979) formulated this concept which is a subjective attitude to one's own disease arising from its evaluation. The resulting image is due to cognitive reactions depending on the processing and 
coding of all messages received that bear any relation with the disease. The most common sources of information are health care providers, other patients, family, friends, the medical literature and the media, together with the patient's well-being and their disease symptoms [8].

Every person possesses a certain amount of knowledge about their illness. Having the disease diagnosed, increases receiving this from the resources as previously mentioned. Several factors have been found to govern how this information is received; above all:

- an individual's education and intellectual capacity,

- the patient's current state of health their emotional situation,

- the patient's attitude towards the information sources,

- the environment surrounding a person's life.

Because of the diversity of determinants that make up one's self-image of the disease, it may differ greatly and is most often incomplete. Much depends on the level of information received and then adopted [9].

The pathological image as formed by an ill person very significantly affects their mental resolve and behavior. This is about actions taken after the diagnosis is confirmed which impact on improving health and self-coping with the disease.

The way in which patients perceive their image will also hugely affect the medical care providers. The most important elements for making contact with the patients are empathy, dedicating sufficient time and the ability to properly communicate. It is essential that the information provided be suited to the patient's level of understanding. Using medical jargon, which is often incomprehensible to the patient, may have adverse effects and arouse anxiety.

As soon as the patient is diagnosed, and throughout their subsequent stages of treatment, different emotions will come into play such as fear, anxiety, anger, resignation. Most are negative and are dominated by fear of the future and of living. There is nevertheless, also one very intense and positive feeling, namely that of hope. This permits an optimistic look into the future and for gathering strength for continuing the battle against the disease. It becomes a balancing force against the fear.

The fear of developing cancer stems from the conviction that this involves great suffering and is mainly due to the simplified public image that cancer is incurable. An inadequate knowledge about cancer serves only to heighten the anxiety and the fear experienced. The anxiety relates both to the future, which for cancer patients becomes more uncertain, and towards the past, leading to a negatively balanced view of life. At such moments patients frequently lose their sense of life's purpose [10].

To reduce anxiety, it is necessary to have accurate information about the disease, the treatment options, prognosis and to support patients so as to motivate them for battling the disease. In our study, 30 women (37.5\%) replied that they received most of the information from a doctor at diagnosis. Such information however was not exhaustive as was noted from the subjects responses.

Women have many understandable doubts and dilemmas about their disease. Unfortunately, patients frequently do not have the opportunity to ask the questions that are bothering them, because the time spent with their specialist is often limited. That is why they feel embittered and helpless. Sometimes they are also angry at the doctors, nurses and the entire health care system, which to them seems unfeeling. As a rule they search the internet and gather up plenty of various information, not really knowing what can be useful, and what is irrelevant [11].

When women are asked the reason why they have insufficient information, the most frequent answer is that doctors lack the time to give it. Regarding the question on who provided the most information about treatment, the possible complications, prognosis, prevention, anti-edematous treatment and post-mastectomy procedures, then 19 women (24\%) stated it was from the doctor whilst 16 (20\%) reported it was from the 'Amazon Club', (Fig. 6).

Nowadays there is no doubt that doctor's mistakes are in neglecting to provide guidance on nutrition, sex life and ability to perform one's professional work. Cancer patients are much inclined to read books of the type 'Starvation and Cancer' or 'A healthy vegetarian diet in the treatment of cancer' and others. It is thereby the doctor's duty to always inform the patient about the type of treatment and its possible side effects; of course which the patient may or may not accept [12].

Judging from the subjects' replies there appears to be, above all else, a lack of comprehensive information about possibilities of breast reconstruction, and if already performed, then about any likely complications so arising or the side effects. Similar opinions can be found in the literature.

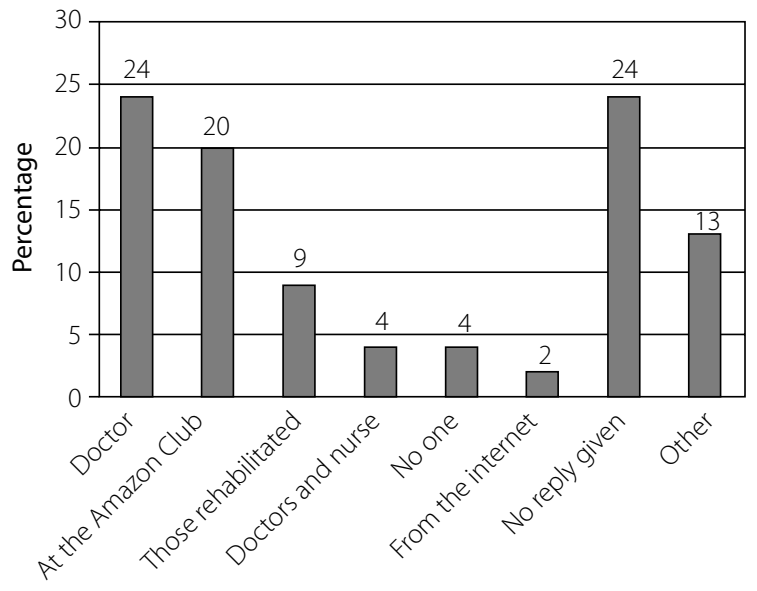

FIGURE 6. Assessing who provided the patient with the most information on treatment methods, possible complications, prognosis, anti-edematous treatment and postmastectomy procedures 
It is commonly stated that silicone implants require supplementation with fluid but doctors do not explain such matters, whilst strongly urging patients for breast reconstruction [6].

Certainly the point is not to persuade the patient that breast reconstruction should always be done. This is a big decision and needs to be taken only after the women have had a thorough consultation with their doctor. Having concrete and full information allows women to decide on their future life-perspectives. Most of the women surveyed gave age as the reason for not having more operations. Some of them, if they had today's knowledge (after mastectomy), would have undergone breast reconstruction surgery. Unfortunately, among the study subjects, there were also those to whom breast restoration was not proposed nor was the matter discussed.

Today however, it is very unlikely that a situation should arise that the patient is not informed about breast reconstruction options.

The technological advances made in reconstructive breast operations, together with the growing understanding about the psychological effects of mastectomy, has made such treatments gain a permanent place as part of the modern and comprehensive armory against breast cancer [13].

Currently, patients usually know about the option of breast restoration however, they are unaware that their perceived wishes may not in reality be feasible. Doctors frequently do not discuss the different stages of reconstruction, or least not at the beginning. The worst being however, is when the woman expects that her new breasts will be the same as before. If the women is also a demanding perfectionist, then she will certainly be dissatisfied leading to further unnecessary corrective procedures. It should be remembered that in breast reconstruction, not only is the body's acceptance vital but also that of the psyche [6].

It is therefore necessary for a consultation with psychologist to be held in order that women realize that their breasts will not be the same as before, despite mod-

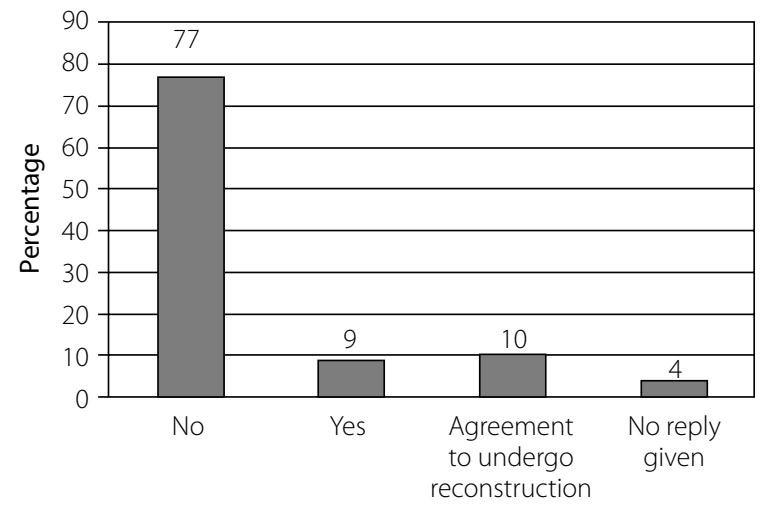

FIGURE 7. Survey responses on whether patients wish to undergo breast reconstruction ern technological progress. Just like for any other surgical procedure, one should keep in mind that outcomes may not be successful. All surgery, including breast reconstruction, entails a risk of failing [6].

Nevertheless, the literature clearly demonstrates that a large proportion of women who underwent breast reconstruction are in fact happy with the final results. This is supported by studies conducted by the Department of Plastic Surgery and Burns Treatment at the Gdansk Medical University between 2000-2003, based on surveying women's satisfaction after their breast reconstructive surgery. Findings showed that $20 \%$ of subjects were highly satisfied, $55 \%$ assessed their satisfaction as good and $25 \%$ as sufficient [13]. Those not wishing to have undergone breast construction surgery in the first place (62 women; $77 \%$ of the total study group), gave age or their health status as reasons (Fig. 7).

The number of women undergoing breast reconstruction after mastectomy is growing. It is therefore very important that the information is provided in the right manner and is of adequate scope concerning the procedure and any complications that may occur. When deciding on the best surgical option, the patient should be made aware of all the possible ways of reconstruction, their pros and cons and the optimal period of reconstruction. This being linked to the necessity of using adjuvant treatment of cancer [14].

Our study found that 45 subjects (56\%) replied yes to the question of whether they were informed on the possibility of having breast reconstruction (Fig. 8).

Fortunately, women's awareness today are generally much greater than it was before. This is primarily thanks to the Amazon Clubs. Although now, such clubs have become very active and try to be noticed, the information received by women suffering from cancer still remains insufficient. Medical personnel still do not provide enough information, either from a lack of time or from being insufficiently trained.

In western countries, women are taught on how they should talk to doctors and how to ask questions like:

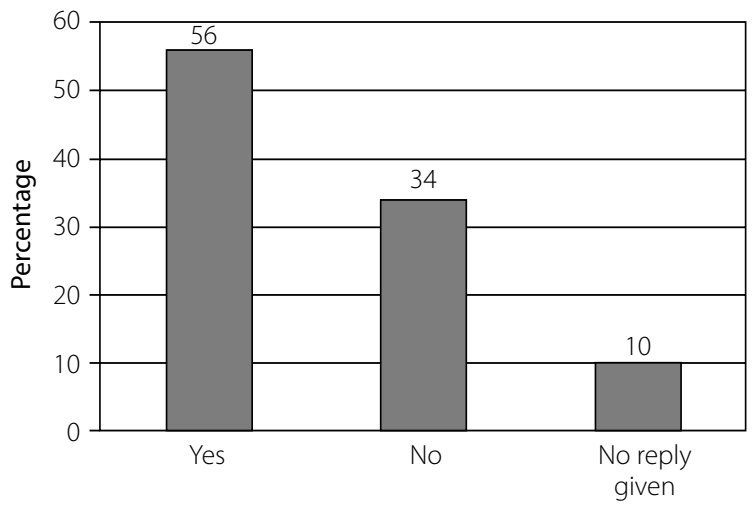

FIGURE 8. Numbers of women informed about the possibilities of breast reconstruction 
'What type of cancer have I got?', 'What is my prognosis?', 'What are the treatments available?', 'What do you envisage for me?' and 'What they are the next steps?' All these questions are succinct and very businesslike. In Poland, the Amazon Clubs in like fashion now train women patients coming to them [6].

A doctor treating a new patient quite often accepts it as just another case, but yet each person is different and therefore their reaction to any given diagnosis can also be different. Even patients who are again in such similar situations can react completely differently [15].

At the moment the vast majority of patients expect to receive comprehensive information about their condition, treatment and prognosis. The truth must not be concealed.

In replying to the question: 'In consultations with your treating doctor, did they provide comprehensive information about the disease, treatment and life after surgery?' 54 women (67\%) replied yes whilst 24 (30\%) stated no (Fig. 9).

Not fully informing the patient should be treated as an affront to his legal right to know because knowing about any immediate threat could change one's life and plans. Furthermore, giving false information or a better-than-really-is prognosis, can stop patients from conducting their affairs in the proper way as opposed to if they had been made aware of the gravity of their particular circumstances [15].

The way in which patients are informed is really important and very much depends on the person; especially in the case of cancer. Relaying information does not take place all at once, but should be regarded as a process consisting of several stages. Upon hearing their diagnosis patients become extremely stressed and are unable to recall everything that the has said.

Cancer patients need time to come to terms with the information they receive. The whole process is thus divided into different stages and associated with varied feelings [15]

One's doctor should make the patient understand that he is always disposed to answer troubling questions, e.g. at the next visit, or to direct the patient to someone else who can provide satisfactory and complete answers; sometimes even better than the doctor can. However, when it comes to discussing the actual surgical techniques used and type of adjuvant therapy then none other but the doctor is best suited for doing this. There remain other topics on breast cancer that others could handle such as physiotherapists or Amazon Club members.

Women who themselves underwent mastectomy and then treatment are an indispensable source of support when those diagnosed with breast cancer are being treated.

The field of modern nursing is constantly developing and is inseparably linked to universally accepted theories and models, in which the patient is treated holistically; meaning that making a diagnosis requires an individual and multi-dimensional approach. As a partner, the patient should actively participate in the process of treatment, nursing and rehabilitation. The idea being that, through health education, everyone is prepared to take responsibility for their own health and life. Above all, this means that a disease should be regarded as a challenge and a battle for one's health and life.

That is why it is vital that women also receive psychological care from the moment a diagnosis is made.

Some consider that cancer is rated as being the most psychologically aggravating and the most stressful (Juczynski, 2000) [9].

Being diagnosed is only the beginning of the road that a patient goes through during treatment. Mental readjustment is needed by the patient to reach the next treatment stage without encountering problems. In reality there are no guarantees that complications will never happen so internal motivation and finding the strength for battle are crucial [6].

Of the 80 subjects asked the question: 'Did the treatment stages include any psychological care?', then 25 women $(31 \%)$ replied yes but $50(62 \%)$ replied no (Fig. 10). This begs the question why do so many women not receive psychological care in this day and age, when so much has been said and written about how important mental wellbeing is addition to physical health.

Breast surgery is a traumatic experience for women which affects their mental function, especially in their emotional life. The most visible signs are depression and hostility to their surroundings caused by a sense of permanent injury to one's own body and of losing confidence in the body. Studies on the emotions of women with breast cancer indicate significantly elevated levels of anxiety during almost all stages and types of treatment [3].

To alleviate this symptom, delivering psychological care is necessary to all women after diagnosis and for it to be continued throughout treatment. Perhaps not all

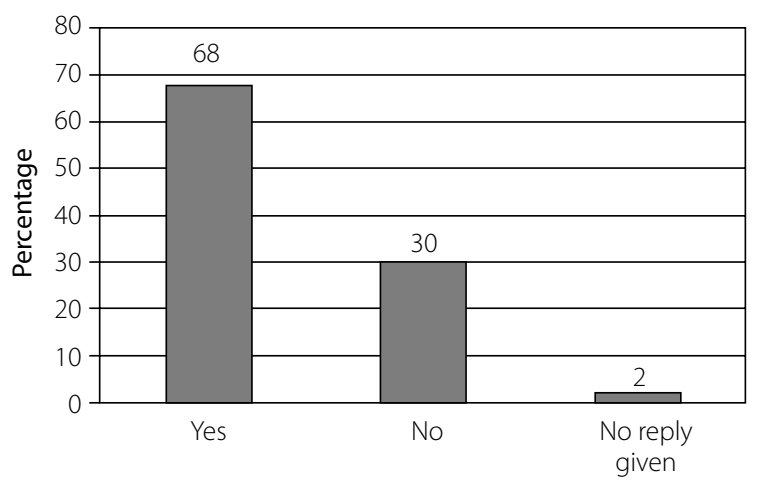

FIGURE 9. Women's opinions on whether they received comprehensive information about the disease, treatment and on life after surgery from their doctor 


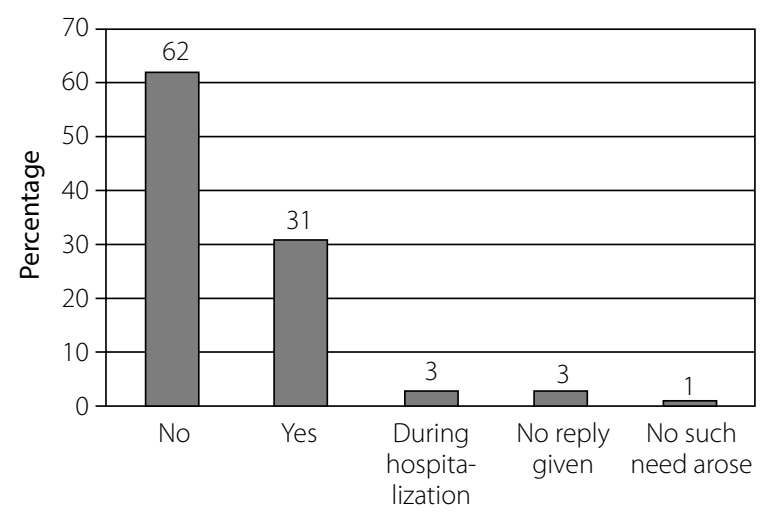

FIGURE 10. Numbers of women that received psychological care during the stages of their treatment

patients are equally in need of this assistance, but any studies aimed at determining this will inevitably require a patient group not receiving any psychological care at all; which is clearly unacceptable.

Doctors consider that in curing a serious disease, the decisive factor is a matter of the patient's willpower: 'I have to live, because...' [3].

Talking to a psychologist can allow this willpower to be evaluated and, if necessary, strengthened if deemed insufficient.

It is easier to fight for one's own health and life, when one feels needed. There are nonetheless single/solitary

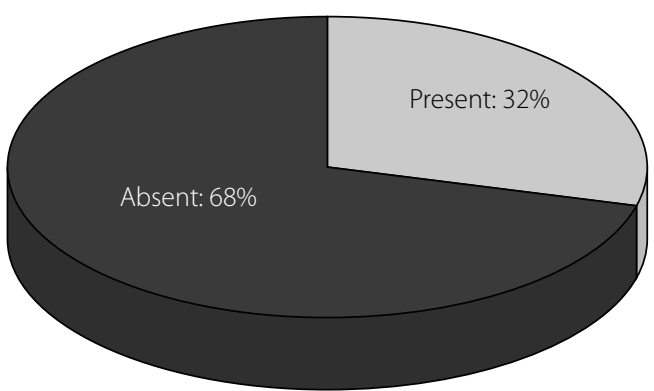

FIGURE 11. Incidence of upper limb swelling post-mastectomy

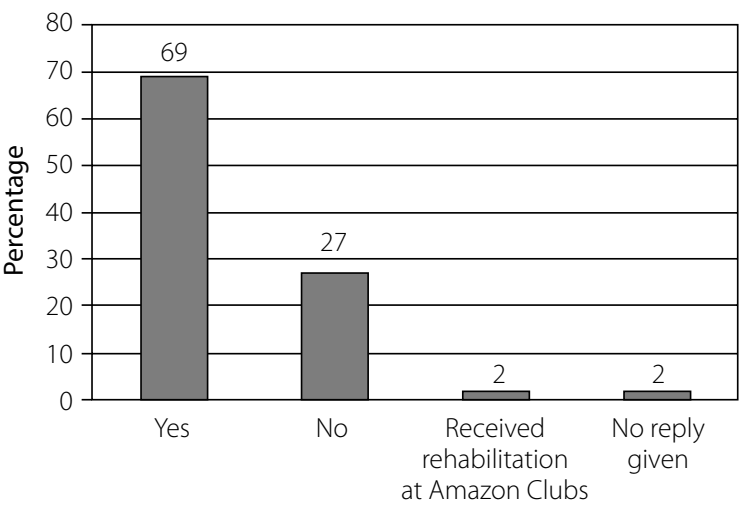

FIGURE 12. Numbers of women sent to rehabilitation after breast surgery people or those whom their partner forsakes when a serious disease has been found. This means that it is much more difficult for them to go through the whole treatment process and will thus require special care on the part of medical staff and psychological care.

At the present, health education issues are assuming increasing importance to medical staff and have become an integral part of their professional duties. According to Ciechaniewicz, the essence of health education 'is to develop the skills required for taking correct decisions to tackle health problems...' [16]. Health education must be about promoting healthy lifestyles as well as for helping a person achieve independence at the onset of the disease or infirmity.

Losing a breast involves a change of posture, where stooping occurs, the shoulder becomes more visually apparent and even leading to a curvature of the spine.

The consequences and complications following surgery should also not be forgotten. An extremely unpleasant complication, especially when surgery involves axillary dissection, is the swelling of the arm. According to the literature this occurs in 6-40\% of women undergoing mastectomy and can arise immediately after surgery or after a few months or even years. In answer to the question: 'Do you have swelling of the upper limb?', 26 women (32.5\%) in our study answered yes and 54 (68\%) replied no (Fig. 11). For people who have lymphedema, the most beneficial treatment would be comprehensive anti-congestive physical therapy and the use of limb motion exercises on the limb-side of the surgery.

It is therefore essential that patients first receive rehabilitation after breast surgery. In the 80 surveyed subjects after surgery, 55 patients (69\%) received rehabilitation, whilst 21 (27\%) did not (Fig. 12).

Rehabilitation is recommended to reduce the physical, mental, social and professional maladjustment caused by the effects of disease or its treatment. This includes both preventive (eg. preventing lymphedema or prophylaxis), as well as health restorative treatments [12].

Given that physical rehabilitation not only serves to prevent or treat lymphedema, but also to improve limb function on the operated side, then for preventing incorrect posture and overall improvement after surgery, all patients should have equal access for its use. Asked why the women subjects were not directed for rehabilitation, they replied: 'I only had rehabilitation at the Amazon Club', 'I don't know why, but I had rehabilitation at the Amazon Club and it was effective, 'It wasn't proposed and I signed myself up for rehabilitation at the Amazon Club, 'I don't know, but I used the rehabilitation organized by Kalisz Amazon Club' and 'It was not'. Such statements show that receiving rehabilitation could only be counted on at the Amazon Club. Because the club was established mainly for providing self-help, it is not geared to providing medical services, and as such, undergoing rehabilitation cannot be limited only to the club. 
Properly conducted rehabilitation should begin when the patient is admitted to the ward for treating breast cancer. However after leaving the hospital, this should be continued in rehabilitation facilities or clinics which carry out the rehabilitation of women after mastectomy. One can also individually perform exercises according to instructors guidance. During outpatient rehabilitation, all women for any stage of breast cancer treatment should be covered by the comprehensive psychophysical-rehabilitation program in accordance with their current status and disease duration [12].

Here are two statements from the study subjects that best reflect what should be said or explained in more detail and amended into women's healthcare post-mastectomy, due to having breast cancer: 'greater psychological support, wider access to rehabilitation, discussion about physical disorders and complications and ways for preventing them' and 'all women should always have equal access to the most modern methods of treatment, rehabilitation, breast reconstruction and prosthetic supplies'.

\section{CONCLUSIONS}

More than half the subjects replied that a diagnosis was made during self examination.

Results confirm that family support is the most significant factor and has the greatest impact on subjects' lives after breast surgery; most reported that this indeed was the case.

The survey demonstrated that not all women with breast cancer received psychological care. Some may not need such help, but at least this should have been offered.

The data gathered on the how patients were prepared for surgery and their lives thereafter showed that the patients were poorly informed. The survey demonstrated that women expect more support and especially to receive detailed and specific information from medical staff. Results indicate that shortcomings in the information provided are due to doctors always being in a hurry and not having sufficient time to devote to patients.

In order that post-mastectomy patients function better in family and working life, rehabilitation is necessary. This should begin at the hospital and continue after leaving. As the survey clearly shows, this unfortunately did not happen to some of the subjects.

\section{References}

1. Jeziorski A, Szawłowski A, Towpik E (eds.). Chirurgia onkologiczna. Vol. 3. PZWL, Warszawa 2009.

2. Bartosz B (ed.). Wymiary kobiecości i męskości. ENETEIA Wydawnictwo Psychologii i Kultury, Warszawa 2011.

3. Sępowicz-Buczko K. Poczucie sensu życia a wsparcie społeczne „Amazonek”. Państwowa Wyższa Szkoła Zawodowa im. Witelona w Legnicy, Legnica 2010.

4. Salmon P. Psychologia w medycynie: wspomaga współpracę z pacjentem i proces leczenia. Gdańskie Wydawnictwo Psychologiczne, Gdańsk 2002.

5. Kordek R, Jassem J, Krzakowski M, Jeziorski A (eds.). Onkologia. Podręcznik dla studentów i lekarzy. Wydawnictwo Medical Press S.C., Gdańsk 2003.

6. Zierkiewicz E. Rozmowy o raku piersi. Trzy poziomy konstruowania znaczeń choroby. Oficyna Wydawnicza ATUT Wydawnictwo Oświatowe, Wrocław 2010.

7. Pisarska-Krawczyk M. Gruczoł sutkowy narządem płciowym kobiety. W: Profilaktyka, rozpoznawanie i leczenie nowotworów narządów płciowych kobiety. I Forum Zdrowia Kobiety. Zeszyt naukowy Nr 7, Wydawnictwo Uczelni PWSZ im. Prezydenta Stanisława Wojciechowskiego w Kaliszu, Kaliszu 2005.

8. Kózka M, Płaszewska-Żywko L (eds.). Modele opieki pielęgniarskiej nad chorym dorosłym - podręcznik dla studiów medycznych. PZWL, Warszawa 2010.

9. Heszen I., Sęk H. Psychologia zdrowia. Wydawnictwo Naukowe PWN, Warszawa 2007.

10. Kirenko J, Byra S. Zasoby osobiste w chorobach psychosomatycznych. Wydawnictwo Uniwersytetu Marii Curie-Skłodowskiej, Lublin 2008.

11. Grobstein RH. Wszystko o raku piersi. W.A.B, Warszawa 2007.

12. Pawlicki M (ed.). Rak piersi - nowe nadzieje i możliwości leczenia. Alfa-medica press, Bielsko-Biała 2011.

13. Nowicki A, Nikiel M. Operacje odtwórcze piersi, ocena satysfakcji pacjentek. Współcz Onkol 2006; 10: 45.

14. Połom K, Murawa D, Wasiewicz J, et al. Rekonstrukcja gruczołu piersiowego u chorych leczonych z powodu raka piersi. Współcz Onkol 2009; 13: 305-308.

15. Dorfmüller M, Dietzfelbinger H (eds.). Psychoonkologia. Diagnostyka - metody terapeutyczne. Elsevier Urban \& Partner, Wrocław 2011.

16. Penar-Zadarko B, Binkowska-Bury M (eds.). Pielęgniarstwo a edukacja zdrowotna. Vol. I. Wydawnictwo Uniwersytetu Rzeszowskiego, Rzeszów 2010.

\section{DISCLOSURE}

Authors report no conflict of interest. 